\title{
Influence of Fly Ash, Organic Manures and Inorganic Fertilizers on Nutrient Uptake of Rice
}

\author{
S. Sheeba ${ }^{1 *}$ and K.Theresa ${ }^{2}$ \\ ${ }^{1}$ Horticultural College \& Research Institute, Trichy, Tamil Nadu, India \\ ${ }^{2}$ Tamil Nadu Agricultural University, Coimbatore, Tamil Nadu, India \\ *Corresponding author
}

\begin{abstract}
A B S T R A C T
Investigation into the effect of fly ash with three organic manures viz., Farm yard manure (FYM), green leaf manu) and Humic acid (HA) and inorganic fertilizers

\section{Keywords}

Fly ash, FYM, GLM, HA, rice, yield uptake

Article Info

Accepted:

15 December 2019

Available Online:

20 January 2020 on the yield and uptake of rice was studied. The test crop was rice variety (ADT 49) Field experiment was conducted during 2014-15 in Krishi Vigyan Kendra, Tirur, Tamil Nadu Agricultural University. Fly ash generated from Mettur Thermal Power Station was selected for the study and examined for its physical and chemical properties. Analysis of fly ash revealed that it is neutral to alkaline $(\mathrm{pH} 8.1)$ in reaction. The results confirmed that fly ash contains all the essential elements required for the plant growth as that of soil except organic carbon and nitrogen. It was observed that fly ash (@20 t ha $\left.{ }^{-1}\right)+$ GLM (@6.25 $\mathrm{t} \mathrm{ha}^{-1}$ )with RDF (150:50:50) supported maximum growth, yield and uptake. The treatment which received fly ash + GLM with RDF (150:50:50) recorded the highest grain $\left(5.49 \mathrm{t} \mathrm{ha}^{-1}\right)$ and straw yield $\left(6.59 \mathrm{t} \mathrm{ha}^{-1}\right)$. The highest nutrient uptake by the grain and straw were observed under the treatment of fly ash+ GLM with RDF. Thus the integrated effect of fly ash, manures and fertilizer was well pronounced in improving the productivity of rice.
\end{abstract}

\section{Introduction}

In India, more than 70 per cent of energy needs are met by coal based thermal power plants (Merajul et al., 2010). Burning of coal produces huge quantity of fly ash. Chemically, fly ash contains oxides, hydroxides, carbonates, silicates, and sulfates of calcium, iron, aluminum, and other metals in trace amount (Adriano et al., 1980). The mineralogical, physical and chemical properties of fly ash depend on the nature of the parent coal, conditions of combustion, type of emission control devices and storage and handling methods. Formation of fly ash depends on the ash content of coal and Indian coal used in power plants generally has very high ash content (35-45\%) and is of lower quality (Mathur et al., 2003). Presence of essential plant nutrients such as $\mathrm{N}, \mathrm{P}, \mathrm{K}, \mathrm{Ca}$, 
$\mathrm{Mg}, \mathrm{S}$ and micronutrients make it a source of plant nutrients and increases yield of several crops after application. Fly ash increased the yield in various crops by 20-25\% with high nutritional value and found beneficial for soil and crop when it was applied in minimal quantity (Yavarzadeh et al.,)

Rice is the staple food for majority of the population in the world. In south India, rice is the major food grain, which is cultivated under wet conditions. Recent high yielding rice varieties remove huge quantity of nutrients from the soil and hence to sustain rice productivity, these nutrients are to be replaced through fertilizers. Utilization of fly ash in rice farming as a source of nutrient will help to sustain rice productivity. However, a proper management strategy has to be developed to abate the land pollution from the dumping of fly ash. Hence, with a view to study the possibility of using fly ash as a component of integrated plant nutrient supply system in rice crop, the present study was initiated.

\section{Materials and Methods}

In the present experiment, Mettur Thermal Power plant was selected as a source of fly ash. The properties of the fly ash were completely studied. The experiment was designed with split plot design replicated three times with four main plot treatments and seven sub plot treatments. In main plot fly ash (FA) @20 t ha ${ }^{-1}$ was applied along with different organics namely Farm Yard Manure (FYM), humic acid (HA) and Green Leaf Manure (GLM - Glyricidia), ( $\mathrm{M}_{0}-\mathrm{FA}$ alone; $\mathrm{M}_{1}$ - FA + FYM (@12.5 t ha ${ }^{-1}$ ); $\mathrm{M}_{2}$ Fly ash + HA (@15 liters ha ${ }^{-1}$ ); $\mathrm{M}_{3}$ - Fly ash + GLM (@6.25 t ha $\left.{ }^{-1}\right)$ ). The sub plot treatments comprised of fertilizer treatments as listed: $\mathrm{S}_{0}-$ No Fertilizer; $\mathrm{S}_{1}-100 \% \mathrm{RDF}$ (150:50:50) kg NPK ha ${ }^{-1}+\mathrm{ZnSO}_{4} @ 25 \mathrm{~kg} \mathrm{ha}$ ${ }^{1}+\mathrm{FeSO}_{4} @ 50 \mathrm{~kg} \mathrm{ha}{ }^{-1} ; \mathrm{S}_{2}-\mathrm{NP}+\mathrm{ZnSO}_{4}+$
$\mathrm{FeSO}_{4} ; \mathrm{S}_{3}-\mathrm{NP}+50 \% \mathrm{~K}+\mathrm{ZnSO}_{4}+\mathrm{FeSO}_{4} ;$ $\mathrm{S}_{4}-\mathrm{NPK}+\mathrm{ZnSO}_{4} ; \mathrm{S}_{5}-\mathrm{NPK}+\mathrm{FeSO}_{4} ; \mathrm{S}_{6}-$ NPK. The fly ash was quantified and applied as a basal dose ten days before transplanting. The GLM and FYM were applied one week before transplanting. The recommended dose of $\mathrm{N}, \mathrm{P}$ and $\mathrm{K}$ fertilizers were applied as per the treatment schedule. The crop was harvested at maturity stage and the yield (grain and straw) and nutrient uptake were recorded.

\section{Results and Discussion}

\section{Characteristics of fly ash}

The fly ash was neutral in soil reaction (8.1) and non-saline $\left(0.24 \mathrm{dSm}^{-1}\right)$. Particle size analysis evinced its texture as silt loam. The physical properties viz., bulk density, particle density, porosity and water holding capacity were $1.24\left(\mathrm{Mg} \mathrm{m}^{-3}\right), 1.99\left(\mathrm{Mg} \mathrm{m}^{-3}\right), 42$ per cent and 33 per cent respectively. The CEC of fly ash was $2.1 \mathrm{c}$ mol $\left(\mathrm{p}^{+}\right) \mathrm{kg}^{-1}$ and organic carbon was found to be 0.01 per cent. The fly ash were analysed chemically for the total $\mathrm{N}$, $\mathrm{P}, \mathrm{K}$, micronutrients and heavy metal content. The total $\mathrm{N}$ content of the fly ash was found to be very low (0.04 per cent). With regard to the total $\mathrm{P}$ content, fly ash recorded $(0.22$ per cent) and the total $\mathrm{K}$ was comparatively high (0.51 per cent) among three macro nutrients. The analytical results of DTPA extractable micronutrients viz., $\mathrm{Zn}, \mathrm{Fe}, \mathrm{Cu}$ and $\mathrm{Mn}$ were 6.8, 17.0, 1.5 and $1.3 \mathrm{mg} \mathrm{kg}^{-1}$ respectively. Regarding the total heavy metals, the content of $\mathrm{Cr}$ was $2.1 \mathrm{mg} \mathrm{kg}^{-1}, \mathrm{~Pb} 2.6 \mathrm{mg} \mathrm{kg}^{-1}$ and 1.1 $\mathrm{mg} \mathrm{kg}^{-1} \mathrm{Cd}$

\section{Characteristics of soil}

The $\mathrm{pH}$ of the experimental soil was slightly alkaline in reaction and non saline. The textural analysis revealed that it is silty clay loam in nature. The physical properties viz., bulk density, particle density, porosity and 
water holding capacity were $1.35\left(\mathrm{Mg} \mathrm{m}^{-3}\right)$, $2.64\left(\mathrm{Mg} \mathrm{m}^{-3}\right), 47.3$ per cent and 40.1 per cent respectively. The organic carbon status was medium and the exchange reactions of soil in respect of cations were $13.4 \mathrm{cmol}\left(\mathrm{p}^{+}\right) \mathrm{kg}^{-1}$. The available nutrient status of soil with respect to $\mathrm{N}, \mathrm{P}$ and $\mathrm{K}$ showed high $\mathrm{K}$, medium $\mathrm{P}$ and low $\mathrm{N}$.

\section{Nutrient composition of the manures used in the study}

The different manures used in this study were analysed by adopting standard methods. It was found that FYM contains 0.97 per cent $\mathrm{N}$, 0.58 per cent $\mathrm{P}$ and 0.72 per cent $\mathrm{K}, \mathrm{GLM}$ contains 2.76 per cent $\mathrm{N}, 0.28$ per cent $\mathrm{P}$ and 4.6 per cent $\mathrm{K}$ and $\mathrm{HA}$ contains 3.5 per cent N, 1.5 per cent $P$ and 2.1 per cent $K$. Effect of Fly Ash, Manures and Fertilizers on Nutrient Uptake.

\section{Nitrogen uptake}

Application of fly ash with GLM increased the $\mathrm{N}$ uptake. The highest $\mathrm{N}$ uptake by grain $\left(71.41 \mathrm{~kg} \mathrm{ha}^{-1}\right)$ and straw (28.87 $\left.\mathrm{kg} \mathrm{ha}^{-1}\right)$ was recorded in fly ash + GLM treatment and the least was in fly ash alone $50.40 \mathrm{~kg} \mathrm{ha}^{-1}$ by grain and $22.67 \mathrm{~kg} \mathrm{ha}$ by straw. The increased uptake with the addition of manures was statistically significant. Among the fertilizer treatment RDF registered highest $\mathrm{N}$ uptake of 63.25 and $26.4 \mathrm{~kg} \mathrm{ha}^{-1}$ in the grain and straw respectively. The lowest $\mathrm{N}$ uptake of $59.61 \mathrm{~kg} \mathrm{ha}^{-1}$ by grain and $25.07 \mathrm{~kg} \mathrm{ha}^{-1}$ by straw was recorded in the no fertilizer treatment.

Among the interaction effect, fly ash + GLM with $\mathrm{RDF}$ recorded the highest $\mathrm{N}$ uptake $73.40 \mathrm{~kg} \mathrm{ha}^{-1}$ and $29.50 \mathrm{~kg} \mathrm{ha}^{-1}$ by the grain and straw respectively. The lowest $\mathrm{N}$ uptake of $48.75 \mathrm{~kg} \mathrm{ha}^{-1}$ and $22.20 \mathrm{~kg} \mathrm{ha}^{-1}$ was recorded in the fly ash alone and control (no fertilizer) treated plots. The $\mathrm{N}$ uptake was statistically significant among the interaction of manures with fertilizers. The fly ash would have stimulated the microbial activity by providing all the nutrients which in turn mobilized the native $\mathrm{n}$. The above results corroborated with the findings of Tripathi et al., (2009). Application of RDF recorded the highest $\mathrm{N}$ uptake in straw and grain. The results are in agreement with the findings of Thanunathan et al., (2001). Also, interaction effect of fly ash and GLM with RDF registered the highest uptake of $\mathrm{N}$ in grain and straw. The results were in line with the findings of Das et al., (2013).

\section{Phosphorus uptake}

Similar to the uptake of $\mathrm{N}$, the uptake of $\mathrm{P}$ was also observed in same trend where the uptake was higher in the grain when compared to the straw. Among the manurial treatments, fly ash + GLM had the highest P uptake of $15.22 \mathrm{~kg} \mathrm{ha}^{-1}$ in grain and $8.96 \mathrm{~kg}$ $\mathrm{ha}^{-1}$ in straw followed by fly ash + FYM scored $14.38 \mathrm{~kg} \mathrm{P} \mathrm{ha}^{-1}$ in grain and $8.57 \mathrm{~kg} \mathrm{P}$ $\mathrm{ha}^{-1}$ in straw. The lowest $\mathrm{P}$ uptake of $7.34 \mathrm{~kg}$ $\mathrm{P} \mathrm{ha}^{-1}$ in grain and $5.35 \mathrm{~kg} \mathrm{P} \mathrm{ha}^{-1}$ in straw was recorded in unmanured (fly ash alone) treatment. With regard to the varied levels of fertilizers, the application of RDF recorded the highest uptake of $13.05 \mathrm{~kg} \mathrm{P}^{-1}$ in grain and straw (7.77 kg P ha $\left.{ }^{-1}\right)$, and in the control (no fertilizer) $\mathrm{P}$ uptake was decreased to 7.38 $\mathrm{kg} \mathrm{P} \mathrm{ha}{ }^{-1}$. With regard to the interaction of fly ash, manures and fertilizers, the treatment fly ash + GLM with RDF registered highest P uptake of $16.25 \mathrm{~kg} \mathrm{ha}^{-1}$ and $9.14 \mathrm{~kg} \mathrm{ha}^{-1}$ by the grain and straw and the least uptake of $6.80 \mathrm{~kg} \mathrm{ha}^{-1}$ and $5.24 \mathrm{~kg} \mathrm{ha}^{-1}$ was observed in the fly ash with no fertilizer treatment. The interaction between different treatments integrated with varied levels of fertilizers was not statistically significant in terms of $\mathrm{P}$ uptake by grain but the case was significant for straw. Urvashi et al., (2007) also recorded similar results where the $\mathrm{P}$ release from fly 
ash was high when it was combined with organic manures. Application of RDF recorded the highest $\mathrm{P}$ uptake followed by RDF with $50 \% \mathrm{~K}$. The results are in line with the findings of Singh and Raunaq (2012). The effect of interaction of fly ash and manures with RDF also showed higher $\mathrm{P}$ uptake. The results corroborated with the findings of Das et al., (2013).

\section{Potassium uptake}

Application of fly ash + GLM recorded the highest mean $\mathrm{K}$ uptake $7.52 \mathrm{~kg} \mathrm{~K}$ ha $^{-1}$ in grain and $90.32 \mathrm{~kg} \mathrm{~K} \mathrm{ha}^{-1}$ in straw. With regard to varied level of fertilizers, RDF treatment showed a marked and highest level of $\mathrm{K}$ uptake by the grain $\left(6.72 \mathrm{~kg} \mathrm{~K} \mathrm{ha}^{-1}\right)$ and straw $\left(72.86 \mathrm{~kg} \mathrm{~K} \mathrm{ha}^{-1}\right)$. In the control plot the $\mathrm{K}$ uptake was low in both $\left(5.72 \mathrm{~kg} \mathrm{ha}^{-1}\right)$ grain and straw $\left(70.86 \mathrm{~kg} \mathrm{ha}^{-1}\right)$. With regard to the interaction effect, application of fly ash + GLM with RDF recorded highest $\mathrm{K}$ uptake of $7.90 \mathrm{~kg} \mathrm{~K} \mathrm{ha}^{-1}$ and $91.40 \mathrm{~kg} \mathrm{~K} \mathrm{ha}^{-1}$ by the grain and straw. The lowest value of $3.75 \mathrm{~kg}$ $\mathrm{K} \mathrm{ha}^{-1}$ and $33.35 \mathrm{~kg} \mathrm{~K} \mathrm{ha}^{-1}$ was recorded in the fly ash without manure and fertilizer. The interaction of graded level of fertilizers with different manurial treatments was not statistically significant in grain uptake of $\mathrm{K}$. The results were in line with the findings of Balasubramaniam (2003). The probable root growth, supply of nutrient and conducive physical environment created on account of addition of fly ash in combination with FYM to the soil would have facilitated better absorption of N, P and K (Das et al., 2013).

\section{Micronutrients uptake}

\section{Zinc (Zn) uptake}

The uptake of $\mathrm{Zn}$ in grain and straw were assessed at the harvest stage of the crop. The $\mathrm{Zn}$ uptake was increased with the manurial application. Among the main treatments the application of fly ash + GLM showed the highest $\mathrm{Zn}$ uptake of $155.9 \mathrm{~g} \mathrm{Zn} \mathrm{ha}^{-1}$ in grain and $237.3 \mathrm{~g} \mathrm{Zn} \mathrm{ha}^{-1}$ in straw followed by fly ash + FYM registered $150.7 \mathrm{~g} \mathrm{Zn} \mathrm{ha}^{-1}$ in grain and $222.5 \mathrm{~g} \mathrm{Zn} \mathrm{ha}^{-1}$ in straw. The unmanured treatment (fly ash alone) recorded the lowest $\mathrm{Zn}$ uptake of $83.2 \mathrm{~g} \mathrm{Zn} \mathrm{ha}^{-1}$ in grain and 120.7 $\mathrm{g} \mathrm{Zn} \mathrm{ha}{ }^{-1}$ in straw. The varied levels of fertilizer have increased the uptake of zinc, among which the RDF treated plots showed a highest $\mathrm{Zn}$ uptake in grain (135.2 $\mathrm{g} \mathrm{Zn} \mathrm{ha}^{-1}$ ) and straw (203.6 $\mathrm{g} \mathrm{Zn} \mathrm{ha}^{-1}$ ). The least uptake of $126.1 \mathrm{~g} \mathrm{Zn} \mathrm{ha}^{-1}$ in grain and $193.3 \mathrm{~g} \mathrm{Zn} \mathrm{ha}^{-1}$ in straw was observed in control (without fertilizer). In the interaction effect, fly ash + GLM with RDF showed highest Zn uptake of $159 \mathrm{~g} \mathrm{Zn} \mathrm{ha}^{-1}$ and $239 \mathrm{~g} \mathrm{Zn} \mathrm{ha}^{-1}$ by the grain and straw respectively. The progressive and significant increase in the $\mathrm{Zn}$ uptake was noticed by the application of manurial treatments with different levels of fertilizer and its interaction was statistically significant in both grain and straw.

\section{Copper (cu) uptake}

Application of fly ash and manures with varied levels of fertilizers increased the uptake of $\mathrm{Cu}$ by the grain and straw. The uptake of $\mathrm{Cu}$ recorded by the fly ash + GLM (70.16 $\mathrm{g} \mathrm{Cu} \mathrm{ha}^{-1}$ ) was the highest uptake by the grain and straw $\left(90.30 \mathrm{~g} \mathrm{Cu} \mathrm{ha}{ }^{-1}\right)$, followed by fly ash + FYM (68.70 $\left.\mathrm{g} \mathrm{Cu} \mathrm{ha}^{-1}\right)$ in grain and (89.88 $\left.\mathrm{g} \mathrm{Cu} \mathrm{ha}^{-1}\right)$ in straw. The fly ash alone treated plots showed a decreased level of $33.4 \mathrm{~g} \mathrm{Cu} \mathrm{ha}^{-1}$ in grain and $49.57 \mathrm{~g}$ $\mathrm{Cu} \mathrm{ha}{ }^{-1}$ in straw. The manurial treatments showed a marked increase in the $\mathrm{Cu}$ uptake due to the application of fly ash and manures. Regarding the varied levels of fertilizers the highest $\mathrm{Cu}$ uptake in the RDF treatment was $50.95 \mathrm{~g} \mathrm{Cu} \mathrm{ha}^{-1}$ in grain and $79.15 \mathrm{~g} \mathrm{Cu} \mathrm{ha}^{-1}$ in straw and the zero level fertilizers registered the least uptake of $58.20 \mathrm{~g} \mathrm{Cu} \mathrm{ha}^{-1}$ and 76.58 g Cu ha ${ }^{-1}$ in grain and straw respectively. With respect to interaction effect, application 
of fly ash + GLM with RDF registered a highest level of $\mathrm{Cu}$ uptake of $71.35 \mathrm{~g} \mathrm{Cu} \mathrm{ha}^{-1}$ and $91.50 \mathrm{~g} \mathrm{Cu} \mathrm{ha}^{-1}$ by the grain and straw respectively. The least $\mathrm{Cu}$ uptake of $32.25 \mathrm{~g}$ $\mathrm{Cu} \mathrm{ha}{ }^{-1}$ by grain and $49.10 \mathrm{~g} \mathrm{Cu} \mathrm{ha}^{-1}$ by straw was showed by fly ash without manure and fertilizer treatment. The treatment fly ash + GLM along with RDF had superiority over the other treatments in all the varied levels of fertilizers in terms of $\mathrm{Cu}$ uptake.

\section{Iron (fe)uptake}

The uptake of Fe in rice varied greatly. In the grain and straw the uptake ranged from 0.475 to $0.597 \mathrm{~kg} \mathrm{Fe} \mathrm{ha}^{-1}$ and 2.2 to $2.58 \mathrm{~kg} \mathrm{Fe} \mathrm{ha}^{-1}$ respectively. The highest uptake was observed in straw $\left(2.5 \mathrm{~kg} \mathrm{Fe} \mathrm{ha}^{-1}\right)$ and in grain $\left(0.594 \mathrm{~kg} \mathrm{Fe} \mathrm{ha}^{-1}\right)$ with fly ash + GLM application. The fly ash alone treatment registered the least uptake of $0.482 \mathrm{~kg} \mathrm{Fe} \mathrm{ha}^{-1}$ and $2.2 \mathrm{~kg} \mathrm{Fe} \mathrm{ha}{ }^{-1}$ in grain and straw respectively. Application of RDF favoured the highest Fe uptake of $0.55 \mathrm{~kg} \mathrm{Fe} \mathrm{ha}^{-1}$ in grain and $2.4 \mathrm{~kg} \mathrm{Fe} \mathrm{ha}^{-1}$ in straw followed by RDF excluding $\mathrm{K}$ in grain and straw of 0.549 $\mathrm{kg} \mathrm{Fe} \mathrm{ha}{ }^{-1}$ and $2.44 \mathrm{~kg} \mathrm{Fe} \mathrm{ha}^{-1}$ and the other fertilizer treatment also revealed the nearest range of Fe uptake. The zero level fertilizers registered the uptake of 0.54 and $2.44 \mathrm{~kg} \mathrm{Fe}$ $\mathrm{ha}^{-1}$ in grain and straw respectively. The varied levels of fertilizers did not display any significant variation. The interaction between manurial treatments and fertilizers was not significant.

\section{Manganese (mn) uptake}

The uptake of $\mathrm{Mn}$ in the grain and straw revealed that the application of different treatments increased significantly. On revealing the results of $\mathrm{Mn}$ uptake in grain and straw, the values are ranged from 0.28 to $0.42 \mathrm{~kg} \mathrm{Mn} \mathrm{ha}^{-1}$ and 1.1 to $1.28 \mathrm{~kg} \mathrm{Mn} \mathrm{ha}^{-1}$ respectively. Among the treatments, fly ash + GLM showed the highest Mn uptake in grain and straw of 0.4 and $1.2 \mathrm{~kg} \mathrm{ha}^{-1}$ respectively. The uptake of Mn was found to be very low in fly ash alone treatment.

With regard to the varied fertilizer level, the RDF application revealed the highest $\mathrm{Mn}$ uptake in grain $\left(0.37 \mathrm{~kg} \mathrm{Mn} \mathrm{ha}^{-1}\right)$ as well as in straw (1.24 kg Mn ha ${ }^{-1}$ ). The control (without fertilizer) registered a least uptake of $0.35 \mathrm{~kg}$ $\mathrm{Mn} \mathrm{ha}^{-1}$ in grain and $1.23 \mathrm{~kg} \mathrm{Mn} \mathrm{ha}^{-1}$ in straw. Application of fly ash + GLM with RDF recorded the highest uptake of $422 \mathrm{~g} \mathrm{Mn} \mathrm{ha}^{-1}$ and $1280 \mathrm{~g} \mathrm{Mn} \mathrm{ha}^{-1}$ by the grain and straw respectively. Among the interactions, the lowest Mn uptake was shown in the fly ash alone without fertilizer treatment. The main treatments interaction with the varied levels of fertilizers showed that the effect was significant.

Under submerged conditions, addition of coal fly ash had pronounced effect on the uptake of $\mathrm{Zn}, \mathrm{Fe}, \mathrm{Cu}$ and $\mathrm{B}$. The uptake was high in fly ash + GLM treated plots followed by fly ash + FYM, fly ash + HA treated plots. The least uptake was recorded in the unmanured plots (fly ash alone). Among the fertilizers levels, RDF registered the highest micronutrients uptake followed by RDF with $50 \% \mathrm{~K}$. The RDF excluding $\mathrm{Zn}, \mathrm{Fe}, \mathrm{Zn}$ and $\mathrm{Fe}$ showed variation in the uptake in small units in both grain and straw. The above results were in corroboration with the findings of Hall and Williams (2003). Similar interaction effect was reported by Das et al., (2013). The increased accumulation of essential ions such as $\mathrm{Zn}, \mathrm{Mn}$ and $\mathrm{Cu}$ by the paddy shoot/grain might be due to increased activity of ionic transporters (Hall and Williams, 2003) in turn due to the higher essential ion availability in the fly ash. 
Table.1 Effect of fly ash, manures and fertilizers on $\mathrm{N}$ uptake $\left(\mathrm{kg} \mathrm{ha}^{-1}\right)$ of rice crop

\begin{tabular}{|c|c|c|c|c|c|c|c|c|c|c|}
\hline \multirow[t]{3}{*}{ Treatments } & \multicolumn{10}{|c|}{ N Uptake (kgha ${ }^{-1}$ ) } \\
\hline & \multicolumn{5}{|c|}{ Grain } & \multicolumn{5}{|c|}{ Straw } \\
\hline & $\mathbf{M}_{\mathbf{0}}$ & $\mathbf{M}_{1}$ & $\mathbf{M}_{2}$ & $\mathbf{M}_{3}$ & Mean & $\mathbf{M}_{\mathbf{0}}$ & $\mathbf{M}_{1}$ & $\mathbf{M}_{2}$ & $\mathbf{M}_{3}$ & Mean \\
\hline $\mathbf{S}_{\mathbf{0}}$ & 48.75 & 64.15 & 57.00 & 68.55 & 59.61 & 22.20 & 25.95 & 23.95 & 28.20 & 25.07 \\
\hline $\mathbf{S}_{1}$ & 51.55 & 55.40 & 61.65 & 73.40 & 63.25 & 23.30 & 27.35 & 25.45 & 29.50 & 26.40 \\
\hline $\mathbf{S}_{2}$ & 51.25 & 65.30 & 60.95 & 71.95 & 62.36 & 22.80 & 27.15 & 25.65 & 29.00 & 26.15 \\
\hline $\mathbf{S}_{3}$ & 51.25 & 65.80 & 60.70 & 72.60 & 62.58 & 22.95 & 27.40 & 24.70 & 29.25 & 26.07 \\
\hline $\mathbf{S}_{4}$ & 50.80 & 65.75 & 60.45 & 71.35 & 62.08 & 22.55 & 27.25 & 24.45 & 29.00 & 25.81 \\
\hline $\mathbf{S}_{5}$ & 50.25 & 65.50 & 60.05 & 71.15 & 61.73 & 22.50 & 26.25 & 24.25 & 28.75 & 25.43 \\
\hline $\mathbf{S}_{6}$ & 49.60 & 65.05 & 58.85 & 70.90 & 61.10 & 22.45 & 25.85 & 24.45 & 28.45 & 25.30 \\
\hline \multirow[t]{2}{*}{ Mean } & 50.49 & 65.42 & 59.95 & 71.41 & 61.81 & 22.67 & 26.74 & 24.70 & 28.87 & 25.75 \\
\hline & \multicolumn{3}{|c|}{ SE d } & \multicolumn{2}{|c|}{$\mathrm{CD}(\mathrm{P}=0.05)$} & \multicolumn{2}{|c|}{ SE d } & \multicolumn{3}{|c|}{$\mathrm{CD}(\mathrm{P}=0.05)$} \\
\hline Main Plot & \multicolumn{3}{|c|}{0.13} & \multicolumn{2}{|c|}{0.43} & \multicolumn{2}{|c|}{0.08} & \multicolumn{3}{|c|}{0.27} \\
\hline Sub Plot & \multicolumn{3}{|c|}{0.14} & \multicolumn{2}{|c|}{0.29} & \multicolumn{2}{|c|}{0.12} & \multicolumn{3}{|c|}{0.25} \\
\hline M at S & \multicolumn{3}{|c|}{0.30} & \multicolumn{2}{|c|}{0.69} & \multicolumn{2}{|c|}{0.24} & \multicolumn{3}{|c|}{0.54} \\
\hline S at M & \multicolumn{3}{|c|}{0.28} & \multicolumn{2}{|c|}{0.59} & \multicolumn{2}{|c|}{0.24} & \multicolumn{3}{|c|}{0.51} \\
\hline
\end{tabular}

Table.2 Effect of fly ash, manures and fertilizers on $\mathrm{P}$ uptake $\left(\mathrm{kg} \mathrm{ha}^{-1}\right)$ of rice crop

\begin{tabular}{|c|c|c|c|c|c|c|c|c|c|c|}
\hline \multirow[t]{3}{*}{ Treatments } & \multicolumn{10}{|c|}{ P Uptake (kg ha $\left.{ }^{-1}\right)$} \\
\hline & \multicolumn{5}{|c|}{ Grain } & \multicolumn{5}{|c|}{ Straw } \\
\hline & $\mathbf{M}_{0}$ & $\mathbf{M}_{1}$ & $\mathbf{M}_{2}$ & $\mathbf{M}_{3}$ & Mean & $\mathbf{M}_{0}$ & $\mathbf{M}_{1}$ & $\mathbf{M}_{2}$ & $\mathbf{M}_{3}$ & Mean \\
\hline $\mathbf{S}_{\mathbf{0}}$ & 6.80 & 13.50 & 12.30 & 15.15 & 11.93 & 5.24 & 8.41 & 7.44 & 8.45 & 7.38 \\
\hline $\mathbf{S}_{1}$ & 7.55 & 15.05 & 13.35 & 16.25 & 13.05 & 5.47 & 8.65 & 7.84 & 9.14 & 7.77 \\
\hline $\mathbf{S}_{2}$ & 7.50 & 14.55 & 13.05 & 16.05 & 12.78 & 5.41 & 8.63 & 7.81 & 9.08 & 7.73 \\
\hline $\mathbf{S}_{3}$ & 7.50 & 14.80 & 13.15 & 16.31 & 12.94 & 5.42 & 8.64 & 7.63 & 9.11 & 7.70 \\
\hline $\mathbf{S}_{4}$ & 7.45 & 14.50 & 12.85 & 15.80 & 12.65 & 5.32 & 8.62 & 7.64 & 9.05 & 7.65 \\
\hline $\mathbf{S}_{5}$ & 7.35 & 14.35 & 12.70 & 15.60 & 12.50 & 5.30 & 8.57 & 7.67 & 9.02 & 7.64 \\
\hline$S_{6}$ & 7.25 & 13.95 & 12.65 & 15.40 & 12.33 & 5.27 & 8.51 & 7.41 & 8.90 & 7.52 \\
\hline \multirow[t]{2}{*}{ Mean } & 7.34 & 14.38 & 12.86 & 15.22 & 12.45 & 5.35 & 8.57 & 7.63 & 8.96 & 7.63 \\
\hline & \multicolumn{3}{|c|}{ SE d } & \multicolumn{2}{|c|}{$\mathrm{CD}(\mathrm{P}=0.05)$} & \multicolumn{2}{|c|}{ SE d } & \multicolumn{3}{|c|}{$\mathrm{CD}(\mathrm{P}=0.05)$} \\
\hline Main Plot & \multicolumn{3}{|c|}{0.35} & \multicolumn{2}{|c|}{1.11} & \multicolumn{2}{|c|}{0.011} & \multicolumn{3}{|c|}{0.036} \\
\hline Sub Plot & \multirow{2}{*}{\multicolumn{3}{|c|}{$\begin{array}{l}0.50 \\
0.99\end{array}$}} & \multicolumn{2}{|c|}{ NS } & \multicolumn{2}{|c|}{0.017} & \multirow{2}{*}{\multicolumn{3}{|c|}{0.035}} \\
\hline$M$ at $S$ & & & & \multirow{2}{*}{\multicolumn{2}{|c|}{ NS }} & \multicolumn{2}{|c|}{0.03} & \multicolumn{2}{|r|}{0.07} & \\
\hline$S$ at $M$ & \multicolumn{3}{|c|}{1.0} & & & \multicolumn{2}{|c|}{0.03} & \multicolumn{3}{|c|}{0.07} \\
\hline
\end{tabular}


Int.J.Curr.Microbiol.App.Sci (2020) 9(1): 2014-2023

Table.3 Effect of fly ash, manures and fertilizers on $\mathrm{K}$ uptake $\left(\mathrm{kg} \mathrm{ha}^{-1}\right)$ of rice crop

\begin{tabular}{|c|c|c|c|c|c|c|c|c|c|c|}
\hline \multirow[b]{2}{*}{ Treatments } & \multicolumn{5}{|c|}{ Grain } & \multicolumn{5}{|c|}{ Straw } \\
\hline & $\mathbf{M}_{\mathbf{0}}$ & $\mathbf{M}_{1}$ & $\mathbf{M}_{2}$ & $\mathbf{M}_{3}$ & Mean & $\mathbf{M}_{0}$ & $\mathbf{M}_{1}$ & $\mathbf{M}_{2}$ & $\mathbf{M}_{3}$ & Mean \\
\hline $\mathbf{S}_{\mathbf{0}}$ & 3.75 & 6.35 & 5.55 & 7.25 & 5.72 & 33.35 & 85.40 & 75.35 & 89.35 & 70.86 \\
\hline $\mathbf{S}_{1}$ & 4.90 & 7.40 & 6.70 & 7.90 & 6.72 & 35.80 & 87.85 & 76.40 & 91.40 & 72.86 \\
\hline $\mathbf{S}_{2}$ & 4.25 & 6.65 & 6.25 & 7.25 & 6.10 & 34.85 & 86.55 & 76.05 & 90.25 & 71.92 \\
\hline $\mathbf{S}_{3}$ & 4.80 & 7.25 & 6.55 & 7.80 & 6.60 & 35.30 & 87.60 & 76.25 & 90.90 & 72.51 \\
\hline $\mathbf{S}_{4}$ & 4.35 & 7.10 & 6.25 & 7.55 & 6.31 & 35.15 & 86.75 & 76.25 & 90.15 & 72.07 \\
\hline $\mathbf{S}_{5}$ & 4.25 & 7.05 & 6.35 & 7.60 & 6.31 & 35.10 & 86.45 & 76.20 & 90.15 & 71.97 \\
\hline$S_{6}$ & 4.30 & 6.70 & 6.10 & 7.35 & 6.11 & 34.85 & 86.10 & 75.80 & 90.05 & 71.70 \\
\hline \multirow[t]{2}{*}{ Mean } & 4.37 & 6.92 & 6.25 & 7.52 & 6.26 & 34.91 & 86.67 & 76.04 & 90.32 & 71.98 \\
\hline & \multicolumn{3}{|c|}{ SE d } & \multicolumn{2}{|c|}{$\mathrm{CD}(\mathrm{P}=0.05)$} & \multicolumn{2}{|c|}{ SE d } & \multicolumn{3}{|c|}{$\mathrm{CD}(\mathrm{P}=0.05)$} \\
\hline Main Plot & \multicolumn{3}{|c|}{0.03} & \multicolumn{2}{|c|}{0.10} & \multicolumn{2}{|c|}{0.05} & \multicolumn{3}{|c|}{0.016} \\
\hline Sub Plot & \multicolumn{3}{|c|}{0.07} & \multicolumn{2}{|c|}{0.14} & \multicolumn{2}{|c|}{0.07} & \multicolumn{3}{|c|}{0.15} \\
\hline$M$ at $S$ & \multicolumn{3}{|c|}{0.13} & \multicolumn{2}{|c|}{ NS } & \multicolumn{2}{|c|}{0.15} & \multicolumn{3}{|c|}{0.33} \\
\hline S at M & \multicolumn{3}{|c|}{0.14} & \multicolumn{2}{|c|}{ NS } & \multicolumn{2}{|c|}{0.15} & \multicolumn{3}{|c|}{0.31} \\
\hline
\end{tabular}

Table.4 Effect of fly ash, manures and fertilizers on $\mathrm{Zn}$ uptake $\left(\mathrm{g} \mathrm{ha}^{-1}\right)$ of rice crop

\begin{tabular}{|c|c|c|c|c|c|c|c|c|c|c|}
\hline \multirow[t]{3}{*}{ Treatments } & \multicolumn{10}{|c|}{ Zn Uptake (kg ha $\left.{ }^{-1}\right)$} \\
\hline & \multicolumn{5}{|c|}{ Grain } & \multicolumn{5}{|c|}{ Straw } \\
\hline & $\mathbf{M}_{\mathbf{0}}$ & $\mathbf{M}_{1}$ & $\mathbf{M}_{2}$ & $\mathbf{M}_{3}$ & Mean & $\mathbf{M}_{0}$ & $\mathbf{M}_{1}$ & $\mathbf{M}_{2}$ & $\mathbf{M}_{3}$ & Mean \\
\hline $\mathbf{S}_{\mathbf{0}}$ & 77.0 & 143.0 & 134.0 & 150.5 & 126.1 & 111.5 & 219.0 & 212.5 & 230.5 & 193.3 \\
\hline $\mathbf{S}_{1}$ & 88.0 & 154.5 & 139.5 & 159.0 & 135.2 & 127.0 & 227.5 & 220.5 & 239.5 & 203.6 \\
\hline $\mathbf{S}_{2}$ & 84.5 & 152.5 & 138.0 & 156.5 & 132.8 & 124.5 & 222.0 & 218.5 & 237.5 & 200.6 \\
\hline $\mathbf{S}_{3}$ & 85.5 & 153.0 & 137.5 & 157.0 & 133.2 & 124.0 & 222.0 & 219.0 & 238.5 & 200.8 \\
\hline $\mathbf{S}_{4}$ & 86.0 & 153.0 & 138.0 & 158.5 & 133.8 & 123.5 & 225.5 & 221.0 & 240.5 & 202.6 \\
\hline $\mathbf{S}_{5}$ & 82.0 & 149.5 & 135.0 & 155.5 & 130.5 & 118.5 & 221.0 & 218.0 & 237.5 & 198.7 \\
\hline $\mathbf{S}_{6}$ & 80.0 & 150.0 & 134.5 & 154.5 & 129.7 & 116.5 & 220.5 & 217.0 & 237.5 & 197.8 \\
\hline \multirow[t]{2}{*}{ Mean } & 83.2 & 150.7 & 136.6 & 155.9 & 131.6 & 120.7 & 222.5 & 218.0 & 237.3 & 199.6 \\
\hline & \multicolumn{3}{|c|}{ SE d } & \multicolumn{2}{|c|}{$\mathrm{CD}(\mathrm{P}=0.05)$} & \multicolumn{2}{|c|}{ SE d } & \multicolumn{3}{|c|}{$\mathrm{CD}(\mathrm{P}=0.05)$} \\
\hline Main Plot & \multicolumn{3}{|c|}{0.19} & \multicolumn{2}{|c|}{0.60} & \multicolumn{2}{|c|}{0.41} & \multicolumn{3}{|c|}{1.32} \\
\hline Sub Plot & \multicolumn{3}{|c|}{0.39} & \multicolumn{2}{|c|}{0.81} & \multicolumn{2}{|c|}{0.51} & \multicolumn{3}{|c|}{1.05} \\
\hline$M$ at $S$ & \multicolumn{3}{|c|}{0.75} & \multicolumn{2}{|c|}{1.60} & \multicolumn{2}{|c|}{1.03} & \multicolumn{3}{|c|}{2.3} \\
\hline S at $M$ & \multicolumn{3}{|c|}{0.78} & \multicolumn{2}{|c|}{1.62} & \multicolumn{2}{|c|}{1.02} & \multicolumn{3}{|c|}{2.1} \\
\hline
\end{tabular}


Table.5 Effect of fly ash, manures and fertilizers on $\mathrm{Cu}$ uptake $\left(\mathrm{g} \mathrm{ha}^{-1}\right)$ of rice crop

\begin{tabular}{|c|c|c|c|c|c|c|c|c|c|c|}
\hline \multirow[t]{3}{*}{ Treatments } & \multicolumn{10}{|c|}{ Cu Uptake $\left(\mathrm{kg} \mathrm{ha}^{-1}\right)$} \\
\hline & \multicolumn{5}{|c|}{ Grain } & \multicolumn{5}{|c|}{ Straw } \\
\hline & $\mathbf{M}_{0}$ & $\mathbf{M}_{1}$ & $\mathbf{M}_{2}$ & $\mathbf{M}_{3}$ & Mean & $\mathbf{M}_{0}$ & $\mathbf{M}_{1}$ & $\mathbf{M}_{2}$ & $\mathbf{M}_{3}$ & Mean \\
\hline $\mathbf{S}_{\mathbf{0}}$ & 32.25 & 68.60 & 63.75 & 68.20 & 58.20 & 49.10 & 87.80 & 80.40 & 89.05 & 76.58 \\
\hline $\mathbf{S}_{1}$ & 34.05 & 69.25 & 65.15 & 71.35 & 50.95 & 50.05 & 90.60 & 84.45 & 91.50 & 79.15 \\
\hline $\mathbf{S}_{2}$ & 33.85 & 68.80 & 64.85 & 70.75 & 59.56 & 49.65 & 90.15 & 84.05 & 90.65 & 78.62 \\
\hline $\mathbf{S}_{\mathbf{3}}$ & 33.75 & 68.95 & 64.50 & 70.55 & 59.43 & 49.45 & 90.25 & 83.65 & 90.45 & $\mathbf{7 8 . 4 5}$ \\
\hline $\mathbf{S}_{4}$ & 33.45 & 68.70 & 64.25 & 70.75 & 59.28 & 49.80 & 90.65 & 84.30 & 91.05 & 78.95 \\
\hline $\mathbf{S}_{5}$ & 33.50 & 68.70 & 64.30 & 70.05 & 59.13 & 49.50 & 89.90 & 84.05 & 90.15 & 78.40 \\
\hline$S_{6}$ & 33.25 & 67.95 & 64.05 & 69.50 & 58.68 & 49.45 & 80.85 & 83.05 & 89.30 & 77.91 \\
\hline \multirow[t]{2}{*}{ Mean } & 33.44 & 68.70 & 64.40 & 70.16 & 59.18 & 49.57 & 89.88 & 83.42 & 90.30 & 78.29 \\
\hline & \multicolumn{3}{|c|}{ SE d } & \multicolumn{2}{|c|}{$\mathrm{CD}(\mathrm{P}=0.05)$} & \multicolumn{2}{|c|}{ SE d } & \multicolumn{3}{|c|}{$\mathrm{CD}(\mathrm{P}=0.05)$} \\
\hline Main Plot & \multicolumn{3}{|c|}{0.11} & \multicolumn{2}{|c|}{0.36} & \multicolumn{2}{|c|}{0.03} & \multicolumn{3}{|c|}{0.9} \\
\hline Sub Plot & \multicolumn{3}{|c|}{0.11} & \multicolumn{2}{|c|}{0.24} & \multicolumn{2}{|c|}{0.05} & \multicolumn{3}{|c|}{0.1} \\
\hline $\mathrm{M}$ at $\mathrm{S}$ & \multicolumn{3}{|c|}{0.24} & \multicolumn{2}{|c|}{0.56} & \multicolumn{2}{|c|}{0.1} & \multicolumn{3}{|c|}{0.2} \\
\hline S at $M$ & \multicolumn{3}{|c|}{0.23} & \multicolumn{2}{|c|}{0.48} & \multicolumn{2}{|c|}{0.1} & \multicolumn{3}{|c|}{0.2} \\
\hline
\end{tabular}

Table.6 Effect of fly ash, manures and fertilizers on Fe uptake $\left(\mathrm{g} \mathrm{ha}^{-1}\right)$ of rice crop

\begin{tabular}{|c|c|c|c|c|c|c|c|c|c|c|}
\hline \multirow[t]{3}{*}{ Treatments } & \multicolumn{10}{|c|}{ Fe Uptake $\left(\mathrm{kg} \mathrm{ha}^{-1}\right)$} \\
\hline & \multicolumn{5}{|c|}{ Grain } & \multicolumn{5}{|c|}{ Straw } \\
\hline & $\mathbf{M}_{0}$ & $\mathbf{M}_{1}$ & $\mathbf{M}_{2}$ & $\mathbf{M}_{3}$ & Mean & $\mathbf{M}_{\mathbf{0}}$ & $\mathbf{M}_{1}$ & $\mathbf{M}_{2}$ & $\mathbf{M}_{3}$ & Mean \\
\hline $\mathbf{S}_{\mathbf{0}}$ & 475 & 566 & 538 & 591 & 542 & 2202 & 2501 & 2487 & 2574 & 2441 \\
\hline $\mathbf{S}_{1}$ & 488 & 572 & 546 & 597 & 551 & 2208 & 2510 & 2493 & 2582 & 2448 \\
\hline $\mathbf{S}_{2}$ & 486 & 571 & 544 & 596 & 549 & 2207 & 2510 & 2492 & 2580 & 2447 \\
\hline $\mathbf{S}_{3}$ & 486 & 571 & 543 & 595 & 549 & 2206 & 2509 & 2491 & 2579 & 2446 \\
\hline $\mathbf{S}_{4}$ & 480 & 570 & 540 & 591 & 545 & 2205 & 2507 & 2490 & 2578 & 2445 \\
\hline $\mathbf{S}_{5}$ & 484 & 662 & 543 & 595 & 571 & 22.07 & 2509 & 2492 & 2580 & 2447 \\
\hline$S_{6}$ & 479 & 570 & 539 & 591 & 545 & 2204 & 2506 & 2464 & 2577 & 2438 \\
\hline \multirow[t]{2}{*}{ Mean } & 482 & 583 & 542 & 594 & 550 & 2205 & 2507 & 2487 & 2579 & 2444 \\
\hline & \multicolumn{3}{|c|}{ SE d } & \multicolumn{2}{|c|}{$\mathrm{CD}(\mathrm{P}=0.05)$} & \multicolumn{2}{|c|}{ SE d } & \multicolumn{3}{|c|}{$\mathrm{CD}(\mathrm{P}=0.05)$} \\
\hline Main Plot & \multicolumn{3}{|c|}{9.11} & \multicolumn{2}{|c|}{28.9} & \multicolumn{2}{|c|}{2.38} & \multicolumn{3}{|c|}{7.5} \\
\hline Sub Plot & \multicolumn{3}{|c|}{12.09} & \multicolumn{2}{|c|}{ NS } & \multicolumn{2}{|c|}{3.46} & \multicolumn{3}{|c|}{7.1} \\
\hline$M$ at $S$ & \multicolumn{3}{|c|}{24.17} & \multicolumn{2}{|c|}{ NS } & \multicolumn{2}{|c|}{6.85} & \multicolumn{3}{|c|}{ NS } \\
\hline S at $M$ & \multicolumn{3}{|c|}{24.18} & \multicolumn{2}{|c|}{ NS } & \multicolumn{2}{|c|}{6.93} & \multicolumn{3}{|c|}{ NS } \\
\hline
\end{tabular}


Table.7 Effect of fly ash, manures and fertilizers on Mn uptake $\left(\mathrm{g} \mathrm{ha}^{-1}\right)$ of rice crop

\begin{tabular}{|c|c|c|c|c|c|c|c|c|c|c|}
\hline \multirow[t]{3}{*}{ Treatments } & \multicolumn{10}{|c|}{ Mn Uptake $\left(\mathrm{kg} \mathrm{ha}^{-1}\right)$} \\
\hline & \multicolumn{5}{|c|}{ Grain } & \multicolumn{5}{|c|}{ Straw } \\
\hline & $\mathbf{M}_{\mathbf{0}}$ & $\mathbf{M}_{1}$ & $\mathbf{M}_{2}$ & $\mathbf{M}_{3}$ & Mean & $\mathbf{M}_{\mathbf{0}}$ & $\mathbf{M}_{1}$ & $\mathbf{M}_{2}$ & $\mathbf{M}_{3}$ & Mean \\
\hline $\mathbf{S}_{\mathbf{0}}$ & 286.0 & 377.0 & 367.5 & 393.0 & 355.8 & 1178.5 & 1242.5 & 1235.5 & 1272.5 & 1232.2 \\
\hline $\mathbf{S}_{1}$ & 297.5 & $400 . .5$ & 380.5 & 422.0 & 375.1 & 1185.0 & 1259.5 & 1253.0 & 1280.5 & 1244.5 \\
\hline $\mathbf{S}_{2}$ & 295.5 & 397.5 & 377.5 & 418.5 & 372.2 & 1184.0 & 1257.5 & 1248.5 & 1277.0 & 1241.7 \\
\hline $\mathbf{S}_{3}$ & 295.0 & 396.0 & 377.5 & 418.5 & 371.7 & 1181.5 & 1257.5 & 1248.5 & 1275.5 & 1240.7 \\
\hline $\mathbf{S}_{4}$ & 294.5 & 396.0 & 379.5 & 420.0 & 372.5 & 1183.0 & 1256.0 & 1250.0 & 1277.0 & 1241.5 \\
\hline $\mathbf{S}_{5}$ & 291.5 & 394.0 & 375.0 & 416.5 & 369.2 & 1181.0 & 1256.5 & 1246.0 & 1275.0 & 1239.6 \\
\hline$S_{6}$ & 290.5 & 390.0 & 370.5 & 405.5 & 364.1 & 1178.5 & 1255.5 & 1244.5 & 1274.0 & 1238.1 \\
\hline \multirow[t]{2}{*}{ Mean } & 292.9 & 393.0 & 375.4 & 413.4 & 368.6 & 1181.6 & 1255.0 & 1246.5 & 1275.9 & 1239.7 \\
\hline & \multicolumn{3}{|c|}{ SE d } & \multicolumn{2}{|c|}{$\mathrm{CD}(\mathrm{P}=0.05)$} & \multicolumn{2}{|c|}{ SE d } & \multicolumn{3}{|c|}{$\mathrm{CD}(\mathrm{P}=0.05)$} \\
\hline Main Plot & \multicolumn{3}{|c|}{0.85} & \multicolumn{2}{|c|}{2.7} & \multicolumn{2}{|c|}{0.58} & \multicolumn{3}{|c|}{1.8} \\
\hline Sub Plot & \multicolumn{3}{|c|}{0.76} & \multicolumn{2}{|c|}{1.5} & \multicolumn{2}{|c|}{0.5} & \multicolumn{3}{|c|}{1.1} \\
\hline $\mathbf{M}$ at $\mathrm{S}$ & \multicolumn{3}{|c|}{1.6} & \multicolumn{2}{|c|}{3.8} & \multicolumn{2}{|c|}{1.1} & \multicolumn{3}{|c|}{2.7} \\
\hline S at $M$ & \multicolumn{3}{|c|}{1.5} & \multicolumn{2}{|c|}{3.1} & \multicolumn{2}{|c|}{1.0} & \multicolumn{3}{|c|}{2.3} \\
\hline
\end{tabular}

The results recorded from the study reveals that fly ash supplies nutrient essential for crops growth and it could be used for crop production. The application of fly ash @20 t $\mathrm{ha}^{-1}+$ GLM @6.25 tha ${ }^{-1}$ along with RDF (150:50:50) had significant effect on uptake of nutrients in rice. Fly ash application enriched the soil with $\mathrm{P}, \mathrm{K}$ and micronutrients led to the relative impoverishment of grain and straw in macro and micronutrients. When combining fly ash with GLM, more pronounced beneficial effects were recorded in the present study. So fly ash when applied along with other organics can be a potential source of nutrient for crops.

\section{References}

Adriano DC, Page AL, Elseewi AA, Chang AC and Straughan I 1980. Utilization of fly ash and other coal residues in terrestrial ecosystems: A review. $J$.
Environ. Qual., 9: 333-344.

Balasubramaniam P 2003. Studies on the utilization of rice straw as a source of silicon and potassium for low land rice in udic haplustalf. Ph.D thesis, Tamil Nadu Agricultural University, India.

Das BK, Chouddury BH and Das KN 2013. Effect of integration of fly ash with fertilizers and FYM on nutrient availability, yield and nutrient uptake of rice in inceptisols of Assam, India. Inter. J. Adv. Res. Techno., 2: 190-207.

Hall JL and Williams LE 2003. Transition metal transporters in plants. J. Exp. Bot., 54: 2601-2613.

Mathur R, Chans S and Tezukat T 2003. Optional use of coal for the power generation in India. Energ Policy.; 31: 319.

Merajul IR, Hisamuddhin and Tanweer A. 2010. Impact of fly ash on vegetative 
growth and photosynthetic pigment concentration of Solanum nigrum L.

Nanobiotech. Universale., 1(2): 133138.

Singh N and Raunaq Singh SB 2012. Effect of fly ash on sorption behavior of metribuzin in agricultural soils. $J$. Environ. Sci. Health B., 47: 89- 98.

Thanunathan K, Imayavarambarn V, Singaravel R and Kandasamy S 2001. Effect of Flyash on Growth, Yield and Nutrient Uptake of Sesame. Inst. Sustasainable Agriculture 16. Cordoba, Spain.

Tripathi RC, Masto RE and Ram LC 2009. Bulk use of pond ash for cultivation of wheat- maize-eggplant crops in sequence on a fallow land Resources. Conser.Recy., 54: 134- 139.

Urvashi R, Ebhin Masto R, Selvi VA, Ram LC and Srivastava NK 2007. Effect of farm manure on the release of phosphorus from fly ash. Remediation Journal., 17: 69-81.

Yavarzadeh MR and Shamsadini H 2012. Safe environment by using fly ash and vermicompost on wheat. In: International conference on transport, environment and civilengineering, held during 25-26 August 2012 at Kuala Lumpur (Malaysia), pp: 146-148.

\section{How to cite this article:}

S.Sheeba and K.Theresa. 2020. Influence of Fly Ash, Organic Manures and Inorganic Fertilizers on Nutrient Uptake of Rice. Int.J.Curr.Microbiol.App.Sci. 9(01): 2014-2023. doi: https://doi.org/10.20546/ijcmas.2020.901.228 